\title{
Corporate Sustaining Members, 1999-00
}

Abitibi-Consolidated Inc.

Louisiana Pacific Canada Ltd.

Alberta Environment, Land \& Forest Service

Newfoundland and Labrador Lumber

Bombardier/Aerospace

Bowater Maritimes Inc.

Producers Association

Ontario Ministry of Natural Resources

Bowater Mersey Paper Co.

Canadian Forest Service, NRC

Canfor Corporation

Chapleau Forest Products Ltd. Co.

Corporation of the City of Sault Ste Marie CPPA

Crestbrook Forest Industries

Daishowa-Marubeni Int. Ltd. Peace River Div.

Davis and Company

P.E.I. Department of Agriculture and Forestry

Pine Falls Paper Company

Repap New Brunswick Inc.

Riverside Forest Products Ltd.

St. Anne-Nackawic Pulp Co. Ltd. Woodlands Division

Stone Container (Canada) Inc.

Stora Forest Industries Limited

Timberjack Inc.

Timberline

Tolko Industries Ltd.

Faculty of Forestry, Lakehead University

Forest Alliance of British Columbia

Town of Hinton

Fraser Paper Inc.

Transenergie F. Gauthier VP

Groupe de Recherche Ecologie Forestière

Uniboard Canada Inc.

IMFNS

Université de Moncton

Industrial Forestry Service Ltd.

University of British Columbia

James MacLaren Industries Inc.

University of New Brunswick, Faculty of Forestry

J.D. Irving Limited

University of Toronto

Jiffy Products (N.B.) Ltd.

KPMG

Weldwood of Canada Limited

West Fraser Mills Ltd.

La fôret modele du bas-Saint-Laurent Inc.

Weyerhaeuser Canada Ltd., BC Division

Lignum Limited

Weyerhaeuser Canada Ltd.

Logging and Sawmilling Journal

Wildfire Equipment Inc.

The Contribution of our Corporate Sustaining Members is Gratefully Acknowledged 